\title{
Not More than Three Tissue Kallikreins Identified from Organs of the Guinea Pig
}

\author{
Franz Fiedler ${ }^{1}$, Gabriele Betz ${ }^{1}$, Heide Hinz ${ }^{1}$, \\ Friedrich Lottspeich ${ }^{2}$, Deshandra M. Raidoo ${ }^{3}$ \\ and Kanti D. Bhoola ${ }^{4} *$ \\ ${ }^{1}$ Abteilung für Klinische Chemie und Klinische \\ Biochemie, Chirurgische Klinik Innenstadt der Universität \\ München, Nußbaumstr. 20, D-80336 München, Germany \\ ${ }^{2}$ Abteilung Proteinanalytik, Max-Planck-Institut für \\ Biochemie, D-82152 M artinsried, Germany \\ ${ }^{3}$ Department of $\mathrm{P}$ hysiology, \\ ${ }^{4}$ Department of Clinical and Experimental Pharmacology, \\ University of Natal - Medical School, Private Bag 7, \\ Congella, 4013 South Africa \\ *Corresponding author
}

The large and varied multigene families of tissue kallikreins of rat and mouse are considered to selectively release as many bioactive peptides. In order to determine whether a similar family of enzymes is expressed in the organs of the guinea pig purification studies were performed. Tissue kallikreins from the submandibular gland, coagulating gland/prostate complex and the pancreas were separated by affinity chromatography on benzamidine-Sepharose. Amino-terminal sequences, the patterns of hydrolysis rates of a number of peptide $p$-nitroanilides, inactivation rates by active site-directed irreversible inhibitors, specific kininogenase activities and types of kinin released were used to probe the identity of the isolated enzymes.

Guinea pig tissue kallikreins $\mathbf{1}$ and $\mathbf{2}$ have been reported previously. In the present study we have identified a third type, designated tissue kallikrein la because of its sequence similarity to kallikrein 1 , which differs from the latter in the catalytic properties. The inferred occurrence of not more than two or three independent tissue kallikrein genes in the guinea pig contrasts with the varied family of enzymes expressed by the large number of such genes present in rats and mice. Expression in the guinea pig (and also in humans) of only a small number of tissue kallikreins makes specific processing of a multitude of biologically active peptides by such enzymes unlikely.

Key words: Amino acid sequences / BenzamidineSepharose / Irreversible protease inhibitors / Kallidin release / Kininogenases / p-nitroanilides.

\section{Introduction}

Tissue kallikreins (TKs) characteristically release kallidin (lysyl-bradykinin) from kininogens by site-specific proteolysis. Kinins are potent vasoactive peptides with possible roles in the maintenance of systemic blood pressure and in the pathogenesis of inflammation (Frey et al., 1968; Erdös, 1979; Bhoola et al., 1992). A large family of enzymes with TK-related sequences has been detected in the mouse with as many as 24 to 25 genes, of which 10 to 14 are functional (Mason et al., 1983; Evans et al., 1987; Berg et al., 1992). A similar large number of 11 to 17 genes has been described in the rat (Wines et al., 1991), and in the African rat M astomys (B owcock et al., 1988). It has been suggested that these enzymes, differing in substrate specificities, are functionally important because of their ability to selectively cleave very many specific polypeptide precursors of bioactive peptides (Mason et al., 1983; Bothwell et al., 1979).

The question whether an analogous regulatory enzyme system is common to each mammalian species is of considerable functional importance. If this were the case one would have to expect the expression of many TK-like enzymes in each mammalian species. In the guinea pig, however, only two different TKs had hitherto been isolated and extensively characterised, including amino acid sequencing. The TK from the submandibular glands (Fiedler et al., 1983) was named guinea pig TK1 (gpK1; B erg et al., 1992), and the second one from the prostate (Dunbar and Bradshaw, 1987) was named guinea pig TK2 (gpK2). An earlier attempt to purify TKs from the guinea pig had resulted in the isolation of not more than one enzyme preparation from each of the organs examined (Mayer et al., 1989). We report here that the Arg esterase activity (a characteristic of TKs) isolated from guinea pig submandibular glands was resolved by affinity chromatography on benzamidine-Sepharose into three different, but similar TK preparations. In order to estimate the number of different TK gene products occurring in other guinea pig organs, the same purification procedure was used on extracts of guinea pig pancreas and coagulating gland/prostate complex (CPC), known to express TK-related enzymes. Three Arg esterases/amidases were isolated from guineapig pancreas, two of which were purified further, whereas only one TK was detected in the coagulating gland/ prostate complex.

Extensive characterisation of these TK preparations indicated that besides gpK 1 and gpK2, only one additional TK, named gpK la, occurs in the guinea pig organs studied. The TK family of the guinea pig appears to consist of the products of not more than three distinct genes. The im- 
plication of this finding for possible functional roles of TK-like enzymes is discussed.

\section{Results}

\section{Isolation of TKs from Submandibular Glands}

During isolation of TKs from organs of the guinea pig precautions were taken against loss of additional tissue kallikrein-like activity, for example a possible fourth submandibular kallikrein. Since TKs are synthesised as proenzymes, homogenates were initially tested for an increase in basal activity following prolonged standing, freezing and thawing, or incubation with bovine trypsin. However, no increase of activity was observed. Column eluates, flow-throughs and final washings with $3 \mathrm{M} \mathrm{NaCl}$ in the respective buffer for elution of strongly bound enzymes were scrutinised for enzyme activity, mainly with the sensitive ester substrate AcPheArgOEt (Fiedler et al., 1983). Column eluates were also screened for Arg amidase activity with the convenient TK substrate D-ValLeuArg-pNA and with SucP heLeuP he-pNA to detect possible enzyme variants with chymotryptic specificity.

Extracts from submandibular glands of male guinea pigs chromatographed on DEAE-Sephadex (Table 1) yielded only one broad peak of Arg esterase activity. The flow-through and final washings with $3 \mathrm{M} \mathrm{NaCl}$ from such columns contained at most $0.01 \%$ or $0.02 \%$ of the total esterase activity, respectively. On rechromatography, the Arg esterase peak became narrower (Mayer et al., 1989). The single peak of $P$ he amidase activity coincided with the Arg esterase activity. When the material of that peak was eluted from a benzamidine-Sepharose column by an ionic strength gradient, it was resolved into three peaks A, B and $C$, which exhibited Arg esterase and amidase activities in similar proportions (Figure 1, Table 1). The SucPheLeuPhe-pNA hydrolysing activity co-eluted with Arg esterase and amidase peaks $A$ and especially $B$ (Figure 1 ).

Rechromatography of peak $A$ on benzamidine-Sepharose (Table 1) removed some contaminating peak B components. During further purification and concentration of the materials of the three peaks $A, B$ and $C$ on hydroxyapatite and DEAE-Sephadex, the ratios of the Arg esterase to amidase and those of the $P$ he to Arg amidase activities remained essentially constant (Table 1). The fractions showing the highest specific activities were combined. Determination of the Phe amidase activity of the TK preparation previously isolated from guinea pig submandibularglands (Fiedler et al., 1983) resulted in a value of $12.9 \%$ of the Arg amidase activity, similar to that obtained for the material of peak $B$.

\section{Isolation of TK from the Coagulating Gland/Prostate Complex (CPC)}

Purification on DEAE-cellulose of a TK-like enzyme from the guinea pig coagulating gland (M oriwaki et al., 1974) as

Table 1 Isolation of Three Tissue Kallikreins from Submandibular Glands of Guinea Pigs.

\begin{tabular}{|c|c|c|c|c|c|c|c|}
\hline \multirow[t]{2}{*}{ Step } & \multirow{2}{*}{$\begin{array}{l}\text { Vol. } \\
\mathrm{ml}\end{array}$} & \multirow{2}{*}{$\begin{array}{l}A_{280} \\
\text { units }\end{array}$} & \multirow{2}{*}{$\frac{A_{280}}{A_{260}}$} & \multicolumn{2}{|c|}{ AcPheArgOEt } & \multirow{2}{*}{$\begin{array}{l}\text { OEt } \\
\text { pNA } \\
U / U\end{array}$} & \multirow{2}{*}{$\begin{array}{l}\text { Phe } \\
\text { Arg } \\
\text { U/U (\%) }\end{array}$} \\
\hline & & & & $U$ & $U / A_{280}$ & & \\
\hline Extract & 125 & 3370 & 0.77 & 4700 & 1.39 & 97 & 7.4 \\
\hline DEAE-Sephadex & 4580 & 1360 & 0.95 & 3810 & 2.80 & 84 & 8.4 \\
\hline DEAE-Sephadex & 1490 & 416 & 1.10 & 3110 & 7.48 & 63 & 10.8 \\
\hline \multicolumn{8}{|l|}{ Benzamidine } \\
\hline A & 61 & 18.6 & 1.23 & 410 & 22.0 & 101 & 2.9 \\
\hline B & 81 & 15.8 & 1.38 & 952 & 60.3 & 79 & 13.0 \\
\hline C & 215 & 5.0 & 0.88 & 60 & 12.0 & 71 & $<1$ \\
\hline Sum A-C & & 39.4 & & 1420 & & & \\
\hline \multicolumn{8}{|l|}{ Peak A } \\
\hline Benzamidine & 55 & 6.6 & 1.00 & 355 & 54 & 122 & 2.1 \\
\hline Hydroxyapatite & 3.6 & 0.92 & 1.49 & 206 & 224 & 104 & 1.7 \\
\hline DEAE-Sephadex & 1.5 & 0.57 & 1.84 & 157 & 275 & 106 & 1.8 \\
\hline \multicolumn{8}{|l|}{ Peak B } \\
\hline Hydroxyapatite & 8.5 & 5.14 & 1.47 & 1270 & 247 & 91 & 14.8 \\
\hline DEAE-Sephadex & 4.3 & 2.93 & 1.85 & 721 & 246 & 84 & 11.7 \\
\hline \multicolumn{8}{|l|}{ Peak C } \\
\hline (Benzamidine) & $(765)$ & $(8.75)$ & $(0.90)$ & (113) & $(12.9)$ & (65) & (1) \\
\hline Hydroxyapatite & 81 & 5.8 & 0.88 & 78 & 13 & 75 & \\
\hline Hydroxyapatite & 5.6 & 7.6 & 0.90 & 55 & 7.2 & 72 & \\
\hline DEAE-Sephadex & 1.7 & 0.136 & 1.22 & 18.8 & 138 & 72 & \\
\hline
\end{tabular}

For details see text and Materials and Methods. OEt/pNA, ratio of AcPheArgOEt/D-ValLeuArg-pNA activities; Phe/Arg, ratio of SucPheLeuPhe-pNA/D-ValLeuArg-pNA activities (expressed in \%). In the purification of peak $C$, material from 4 different runs on benzamidine-Sepharose was combined. 


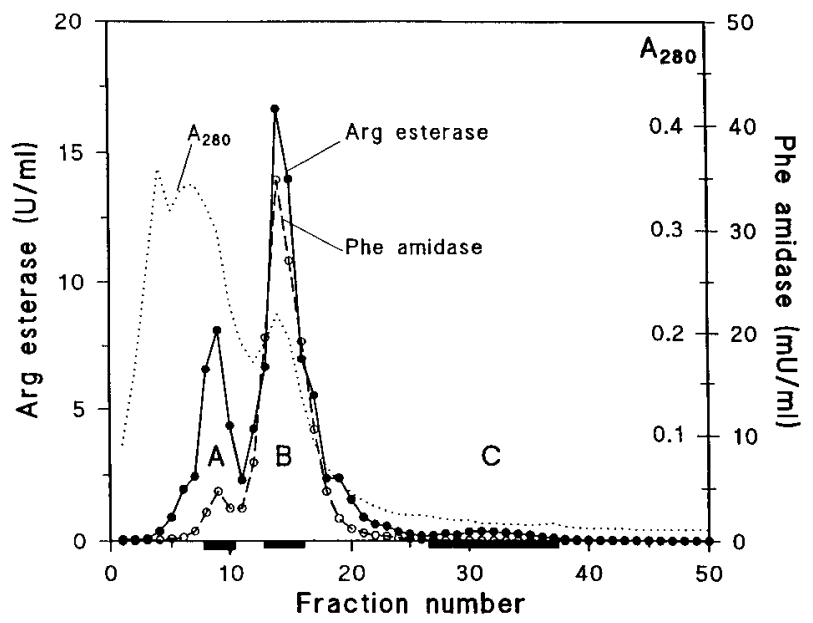

Fig. 1 Resolution of Three Peaks $(A-C)$ of Arginine Esterase from Guinea Pig Submandibular Glands by Gradient Elution from a Benzamidine-Sepharose Column.

For details see Materials and Methods. Fractions pooled are indicated by horizontal bars.

well as one from the prostate (Dunbar and Bradshaw, 1985) has been reported previously. Chromatography of the CPC extracts on DEAE-Sephadex, under comparable conditions, produced a single peak of Arg esterase activity (Table 2), that appeared at a position similar to the Arg esterase activity of the submandibular gland extracts (Mayer et al., 1989). Evidently, the Arg esterase from guinea pig coagulating gland and that from prostate could not be separated by DEAE-Sephadex chromatography. The peak of Phe amidase activity coincided again with the Arg esterase peak, but the Phe amidase activity of the combined eluates amounted to only $0.02 \%$ of the Arg amidase activity. Single peaks of Arg esterase were again observed on subsequent gel filtration and hydroxyapatite chromatography (Table 2).

When small amounts of a DEAE-Sephadex eluate were applied to a benzamidine-Sepharose affinity column, a single Arg esterase peak ( $84 \%$ recovery) and co-eluting Arg-amidase (98\% recovery) and low $(0.01 \%)$ SucPheLeuP he-pNA activities were obtained. When the column was loaded with a 10-fold higher amount of enzyme (Table
2), almost $50 \%$ of the Arg esterase activity was found in a peak $A$, well ahead of the main esterase in peak $B$, which was due to overloading of the column. Rechromatography of peak $A$ gave a single esterase peak, $B_{r}$, with a similar elution profile as peak $B$. Both peaks were pooled for the final DEAE-Sephadex step. The low Phe amidase activity of the CPC enzyme resembled that of the submandibular benzamidine-Sepharose peak C (Figure 1, Table 1). Indeed, when a mixture of submandibular and CPC homogenates was chromatographed on DEAE-Sephadex and the single Arg esterase peak subsequently resolved on benzamidine-Sepharose, the peak of the CPC enzyme coincided with the submandibular peak $C$.

\section{Isolation of TKs from Guinea Pig Pancreas}

On chromatography of pancreas extracts on DEAESephadex, Arg-esterase was found mainly in the flowthrough (presumably cationic trypsin), and in one comparatively minor peak eluting in a region similar to the AcPheArgOEt esterases isolated from the salivary and coagulating glands of the guinea pig (Mayer et al., 1989). On benzamidine-Sepharose ionic strength gradient chromatography, the esterase peak was resolved into three Arg esterase peaks A, B and C (Table 3), in a similar pattern as the three submandibular peaks (see Figure 1, Table 1). The three Arg amidase peaks showed an identical profile to that of the esterase peaks. The Phe/Arg amidase ratios in the fractions of the second main peak $B$ were the highest (Table 3) and similar to the values obtained for the submandibular peak $B$, while those of the other two peaks resembled the submandibular peaks $A$ and $C$, respectively (Table 1). The low $A_{280} / A_{260}$ ratios on further purification of peaks $A$ and $B$ (Table 3 ) were considered to indicate that complete purity had not been attained. The small activity in peak $C$ proved unstable on further purification.

\section{Amino-Terminal Sequences of the TKs}

$\mathrm{N}$-terminal amino acid sequencing of the three submandibular TKs suggested that the enzyme preparations were of satisfactory purity, and that no intrachain cleavage had occurred. Due to the sequencing technique used, Cys

Table 2 Isolation of Tissue Kallikreins from $25 \mathrm{~g}$ of Frozen Coagulating Gland/P rostate Complex of Guinea Pigs.

\begin{tabular}{|c|c|c|c|c|c|c|c|}
\hline \multirow[t]{2}{*}{ Step } & \multirow{2}{*}{$\begin{array}{l}\text { Vol. } \\
\text { ml }\end{array}$} & \multirow{2}{*}{$\begin{array}{l}A_{280} \\
\text { units }\end{array}$} & \multirow{2}{*}{$\frac{A_{280}}{A_{260}}$} & \multicolumn{2}{|c|}{ AcPheArgOEt } & \multirow{2}{*}{$\begin{array}{l}\text { OEt } \\
\text { pNA } \\
U / U\end{array}$} & \multirow{2}{*}{$\begin{array}{l}\text { Phe } \\
\text { Arg } \\
\text { U/U (\%) }\end{array}$} \\
\hline & & & & $U$ & $\mathrm{U} / \mathrm{A}_{280}$ & & \\
\hline Extract & 133 & 2580 & 1.36 & 127000 & 49 & & 0.02 \\
\hline DEAE-Sephadex & 385 & 420 & 2.11 & 130000 & 310 & & \\
\hline Sephadex G-100 & 140 & 353 & 2.12 & 106000 & 300 & & \\
\hline Hydroxyapatite & 227 & 293 & 2.12 & 98000 & 294 & & 0.01 \\
\hline Benzamidine Peak B & 2.5 & 2.47 & 1.62 & 650 & 263 & & \\
\hline (Aliquot) & $(8.0)$ & (11.7) & $(2.12)$ & $(3460)$ & $(294)$ & & $(0.01)$ \\
\hline Benzamidine Peak $B_{r}$ & 4.7 & 1.53 & 1.60 & 365 & 239 & & \\
\hline DEAE-Sephadex & 2.4 & 2.12 & 1.84 & 574 & 271 & 64 & \\
\hline
\end{tabular}

For details see text and Materials and Methods. OEt/pNA, ratio of AcPheArgOEt/D-ValLeuArg-pNA activities; Phe/Arg, ratio of SucPheLeuPhe-pNA/D-ValLeuArg-pNA activities (expressed in \% ). 
Table 3 Isolation of Tissue Kallikreins from $50 \mathrm{~g}$ of Frozen Guinea Pig Pancreas.

\begin{tabular}{|c|c|c|c|c|c|c|c|}
\hline \multirow[t]{2}{*}{ Step } & \multirow{2}{*}{$\begin{array}{l}\text { Vol. } \\
\mathrm{ml}\end{array}$} & \multirow{2}{*}{$\begin{array}{l}A_{280} \\
\text { units }\end{array}$} & \multirow{2}{*}{$\frac{A_{280}}{A_{260}}$} & \multicolumn{2}{|c|}{ AcPheArgOEt } & \multirow{2}{*}{$\begin{array}{l}\text { OEt } \\
p N A \\
U / U\end{array}$} & \multirow{2}{*}{$\begin{array}{l}\text { Phe } \\
\text { Arg } \\
\text { U/U (\%) }\end{array}$} \\
\hline & & & & U & $\mathrm{U} / \mathrm{A}_{280}$ & & \\
\hline Extract & 161 & 6070 & 0.71 & 53.5 & 23 & 11 & \\
\hline DEAE-Sephadex & 2030 & 855 & 0.68 & 53.5 & 0.062 & 110 & \\
\hline DEAE-Sephadex & 560 & 47.0 & 0.82 & 34.5 & 0.73 & 100 & 11 \\
\hline \multicolumn{8}{|l|}{ Benza midine } \\
\hline A & 37 & 5.88 & 1.20 & 5.2 & 0.88 & 110 & 6 \\
\hline B & 29 & 1.61 & 1.00 & 13.7 & 8.5 & 105 & 14 \\
\hline C & 36 & 0.78 & 0.85 & 2.5 & 3.2 & 100 & 0.5 \\
\hline Sum A-C & & 8.27 & & 21.4 & & & \\
\hline \multicolumn{8}{|l|}{ Peak A } \\
\hline DEAE-Sephadex & 2.7 & $(0.52)$ & 0.98 & 1.3 & $(2.5)$ & 109 & 3.4 \\
\hline \multicolumn{8}{|l|}{ Peak B } \\
\hline Hydroxyapatite & 1.7 & 0.16 & 1.02 & 12.7 & 76 & 87 & 11 \\
\hline DEAE-Sephadex & 3.5 & $(0.05)$ & 0.82 & 3.7 & (74) & 79 & 11 \\
\hline
\end{tabular}

Details are given in the legend to Table 1.

residues appeared as blanks. The results obtained were compared to the two known sequences of guinea pig TKs (Table 4). The principal enzyme preparation (Peak B, Figure 1) obtained in the current study was certainly identical with the submandibular enzyme isolated previously (Fiedler et al., 1983), as indicated by the presence of His-20 and Phe-21 and named gpK1 (Berg et al., 1992). When material from Peak $A$ (Figure 1 ) was sequenced, the protein showed His- 20 and Phe- 21 like gpK1, but Lys- 25 like gpK2 (Dunbar and Bradshaw, 1987). Thereafter the sequence remained identical to gpK2 until position 45 and only then differed at Arg-46, Tyr-47 and Ile-49 (Table 4). Resequencing of the previously isolated material from submandibular glands (Fiedler et al., 1983) confirmed the presence of Lys instead of the previously allocated Glu at position 25 of gpK 1 (Table 4, second sequence). The sequence from position 22 to 45 of gpK 1 was the same as that obtained for gpK2. Differences between gpK1 and gpK2 in the first 52 residues were located at only 4 or 5 positions, namely $20,21,47,49$, and possibly 46 . Sub- mandibular gpK 1 and the enzyme from peak $A$ were ind istinguishable in all of the 49 positions sequenced (giving due regard to the tentative nature of position 46) (Table 4). Their molecularmasses on reducing SDS-PAGE were also similar. In accordance with the nomenclature of TK based on sequences (Berg et al., 1992), the newly isolated enzyme from peak A was called gpK 1 . However, because the two TKs differed in their catalytic properties, the new enzyme was named gpKla. Sequencing of the third submandibular benzamidine-Sepharose peak C (Table 2) revealed that the 49 amino-terminal residues were exactly the same as in gpK2, isolated previously from the prostate (Table 4).

When the amino terminus of the only Arg esterase/amidase isolated from guinea pig CPC was sequenced, the 52 positions determined were found to be identical to the sequence reported for prostatic gpK2 (Table 4), except that position 44 seemed to be glycosylated.

The sequence of the benzamidine-Sepharose purified pancreatic peak $B$, the main TK-like Arg-esterase from this

Table 4 Amino-Terminal Sequences of Guinea Pig Tissue Kallikreins gpK1 and gpK2 and of the Newly Isolated Tissue Kallikreins from Guinea Pig Submandibular Glands.

\begin{tabular}{|c|c|c|}
\hline Protein & Assignment & \\
\hline & & $\begin{array}{llll}1 & 10 & 20 & 30\end{array}$ \\
\hline gpK $1 *$ & & VIGGQECARDSHP W qAAVYHF SD I eCGGVLV \\
\hline gpK1 (resequenced) & & VIGGQECARDSHPWQAAVYHFSD I KCGGVLVDPQ $w$ VLTAAXXINdhYQI $\mathrm{L}$ g \\
\hline Submandibular peak A & gpKla & VIGGQECARDSHP WQAAVYHFSD I KCGgVLVDPQ x VLTAAHXIND rYQI \\
\hline Submandibular peak B & gpK1 & VIGGQECARDSHP W QAAVYHF \\
\hline Submandibular peak C & gpK2 & VIGGQECARDSHPWQAAVYYYSDIKCGGVLVDPQ $\times$ VLTAAHX IND SNqV \\
\hline gpK2 $2^{\#}$ & & VIGGQECARDSHP WQAAVYYYSD I KCGGVLVDPQ W VLTAAHC INDSNQV ${ }_{W}^{K}{ }^{L} G$ \\
\hline
\end{tabular}

Tentative identifications of amino acids are indicated by lower case. Amino acids differing from the sequence of gpK 2 are printed in bold. $*$ (Fiedler et al., 1983)

\# (Dunbar and Bradshaw, 1987) 
gland, showed multiple amino acids which could be easily explained by either intrachain cleavages or/and by insufficient purity. However, amino acids corresponding to the common sequence of submandibular gpK 1 and gpK 1 a were clearly observed up to position 19 , together with the characteristic amino acid residues $\mathrm{His}-20$ and Phe-21, but much less Tyr in the latter two positions. These results suggested that the amino-terminal sequence of this pancreatic enzyme resembled that of gpK 1 and not that of gpK2.

\section{Active Site-Directed Irreversible Inhibitors as Probes for Enzyme Identity}

Active site-directed irreversible inhibitors are useful tools for identifying different proteases if the rates of inhibition of the various enzymes differ significantly. Rate constants of inhibition on the main preparations of guinea pig TKs by several of these inhibitors at $\mathrm{pH} 7$ (chosen to retard their hydrolysis) are listed in Table 5.

Diisopropyl fluorophosphate inhibited all three major guinea pig enzymes at moderately different, slow rates. To facilitate comparison with literature data, the second order rate constant $k_{i}=k_{i}^{\prime} /[I]$ in $\mathrm{M}^{-1} \mathrm{~min}^{-1}$ is also given in Table 5. Reaction rates with 4-(2-aminoethyl)-benzene-sulfonyl fluoride (Markwardt et al., 1971) were not much different from those of diisopropyl fluorophosphate, and were similar for the three enzymes. D-PhePheArg $\mathrm{CH}_{2} \mathrm{Cl}$, an efficient chloromethyl ketone inhibitor for both human and rat TKs (Kettner et al., 1980), only moderately discriminated between the three guinea pig TKs (Table 5).

Surprisingly, the Phe chloromethyl ketone ZGlyLeu$\mathrm{PheC} \mathrm{H}_{2} \mathrm{Cl}$ did not inhibit even the submandibular enzyme with the highest Phe amidase activity, gpK1. Only after removal of the $\mathrm{Z}$ residue, the resulting $\mathrm{GlyLeuPheC \textrm {H } _ { 2 } \mathrm { Cl }}$ proved to be a rather effective inhibitor for this enzyme and discriminated strongly (by a factor of 8) between gpK 1 and gpKla (Table 5). A reasonable determination of the very low inactivation rate of CPC gpK2 by GlyLeuPheC $\mathrm{H}_{2} \mathrm{Cl}$ was only possible by raising the inhibitor concentration to
$1 \mathrm{~mm}$. The value in Table 5 for gpK 2 at $20 \mu \mathrm{M}$ inhibitor was calculated by linear extrapolation. Submandibular gpK2 was also inactivated very slowly. Evidently, the inhibition rates of the various TKs parallel their Phe amidase activities.

The unusual inhibition of Arg amidase activities by the Phe compound GlyLeuP he $\mathrm{CH}_{2} \mathrm{Cl}$, and the greatly differing rate constants of inhibition of the three main TKs suggested that this inhibitor may prove useful in characterising also the two guinea pig pancreas enzyme preparations. The limited availability of these enzymes required the use of single samples, and then following rates of inhibition as described under Materials and Methods. Effective inhibition rate constants $\mathrm{k}^{\prime}$ were in the range of $0.5 \times 10^{-3} \mathrm{~s}^{-1}$ for both the pancreatic peak $A$ enzyme and submandibular gpKla (both treated with $0.5 \mathrm{~mm}$ p-amidino-phenylmethanesulfonyl fluoride to eliminate potential tryptic impurities of the pancreatic preparation). Ratios of $k^{\prime}$ from runs with the two enzymes conducted in parallel were $0.954 \pm 0.013$ and $1.029 \pm 0.022$ in two separate experiments. This ratio, being close to 1 (i.e. the $k^{\prime}$ values for the two enzymes are ind istinguishable), was regarded as convincing evidence that the Arg amidase peak $A$ from pancreas represented gpKla. Comparable results for the peak $B$ pancreatic enzyme and submandibular gpK 1 were a $\mathrm{k}^{\prime}$ of about $1.3 \times 10^{-3} \mathrm{~s}^{-1}$ and a ratio of $0.887 \pm 0.040$ ( $n=4$ ), respectively. As this ratio was also near to 1 , it strongly suggested that the Arg amidase activity of the pancreatic peak B was identical with that of submandibulargpK1.

Inactivation constants for submandibular gpK 1 obtained with $20 \mu \mathrm{M}$ GlyLeuPheC $\mathrm{H}_{2} \mathrm{Cl}$ were indistinguishable, whether measured with SucPheLeuPhe-pNA or DValLeuArg-pNA as substrates (Table 5). The similarity between these constants was convincing evidence that both the Arg and the Phe amidase activities were from a single enzyme. For submandibular gpK1a, these inhibition constants were also similar. The distinctly lower rates found for gpK 1 indicate that the Phe amidase activity of gpKla was not due to contamination with gpK 1 .

Table 5 Rates of Inhibition of the Three Major Tissue Kallikrein Preparations from the Guinea Pig by Active Site-Directed Irreversible Inhibitors.

\begin{tabular}{|c|c|c|c|c|c|}
\hline \multicolumn{3}{|l|}{ Tissue kallikrein } & $\begin{array}{l}\text { gpK1 } \\
\text { (Submandibular) }\end{array}$ & \multirow{2}{*}{$\begin{array}{l}\text { gpKla } \\
\text { (Submandibular) }\end{array}$} & \multirow{2}{*}{$\begin{array}{l}\mathrm{gpK} 2 \\
\text { (CPC) }\end{array}$} \\
\hline Inhibitor & Conc. & $t_{\max }$ & Inhibitor constant & & \\
\hline $\begin{array}{l}\text { Diisopropyl } \\
\text { fluorophosphate }\end{array}$ & $1 \mathrm{~mm}$ & $3.5 \mathrm{~h}$ & $\begin{array}{l}0.089 \\
\left(5.3 \mathrm{~m}^{-1} \mathrm{~min}^{-1}\right)\end{array}$ & $\begin{array}{l}0.14 \\
\left(8.4 \mathrm{M}^{-1} \mathrm{~min}^{-1}\right)\end{array}$ & $\begin{array}{l}0.029 \\
\left(1.7 \mathrm{M}^{-1} \mathrm{~min}^{-1}\right)\end{array}$ \\
\hline $\begin{array}{l}\text { 4-(2-Aminoethyl)- } \\
\text { benzenesulfonyl fluoride }\end{array}$ & $1 \mathrm{~mm}$ & $2 \mathrm{~h}$ & 0.15 & 0.17 & 0.30 \\
\hline D-PhePheArg $\mathrm{CH}_{2} \mathrm{Cl}$ & $5 \mu \mathrm{M}$ & $5 \mathrm{~min}$ & 4.6 & 4.5 & 3.9 \\
\hline GlyLeuPheCH${ }_{2} \mathrm{Cl}$ & $\begin{array}{l}20 \mu \mathrm{M} \\
1 \mathrm{~mm}\end{array}$ & $\begin{array}{l}1 \mathrm{~h} ; 2 \mathrm{~h} \\
2 \mathrm{~h}\end{array}$ & $1.22(1.17 *)$ & $0.16(0.19 *)$ & $\begin{array}{l}(0.001) \\
0.050\end{array}$ \\
\hline
\end{tabular}

Conditions: $0.05 \mathrm{M}$ Tris $/ \mathrm{HCl}, 0.1 \mathrm{M} \mathrm{NaCl}, 0.1 \mathrm{~mm}$ EDTA, $\mathrm{pH} 7.0,25.0^{\circ} \mathrm{C}$. Activity determinations with D-ValLeuArg-pNA as substrate (or with SucP heLeuPhe-pNA when indicated by $*$ ). $t_{\max }$, longest time of reaction. Conc. = concentration. 
Table 6 Comparison of the Specific Activities of Tissue Kallikreins with D-ValLeuArg-pNA and Bovine L-Kininogen, and Blood Pressure Lowering Activity in the Guinea Pig.

\begin{tabular}{|c|c|c|c|c|c|c|}
\hline & $\begin{array}{l}\text { gpK1 } \\
\text { (sub- } \\
\text { mandibular) }\end{array}$ & $\begin{array}{l}\text { gpKla } \\
\text { (sub- } \\
\text { mandibular) }\end{array}$ & $\begin{array}{l}\text { gpK2 } \\
\text { (sub- } \\
\text { mandibular) }\end{array}$ & $\begin{array}{l}\text { gpK2 } \\
\text { (CPC) }\end{array}$ & $\begin{array}{l}\text { pK1 } \\
\text { (autolysed } \\
\text { pancreas) }\end{array}$ & $\begin{array}{l}\mathrm{hK} 1 \\
\text { (urine) }\end{array}$ \\
\hline \multicolumn{7}{|l|}{ D-ValLeuArgpNa } \\
\hline$\mu \mathrm{mol} / \mathrm{min} / \mathrm{mg}$ protein & 3.95 & 3.55 & & 5.11 & 4.36 & 4.0 \\
\hline turnover number $\left(\mathrm{s}^{-1}\right)$ & 1.71 & 1.53 & & 2.24 & 1.86 & 1.8 \\
\hline \multicolumn{7}{|l|}{$\begin{array}{l}\text { Bovine L-kininogen } \\
\text { nmol kinin/min/ }\end{array}$} \\
\hline D-ValLeuArg-pNA-U & 68 & 24 & 2.0 & 1.8 & 447 & $(900)$ \\
\hline$\mu \mathrm{mol} \mathrm{kinin/min/mg} \mathrm{protein}$ & 0.27 & 0.085 & & 0.009 & 1.95 & 3.6 \\
\hline turnover number $\left(\mathrm{s}^{-1}\right)$ & 0.12 & 0.037 & & 0.004 & 0.83 & 1.6 \\
\hline \multicolumn{7}{|l|}{ Hypotensive effect } \\
\hline $\mathrm{mg} \mathrm{Bkeq/mg} \mathrm{protein}$ & 670 & 170 & & 60 & & \\
\hline
\end{tabular}

Conditions: $0.1 \mathrm{~mm}$ D-ValLeuArg-pNA or $4.5 \mu \mathrm{m}$ bovine L-kininogen, $0.1 \mathrm{M} \mathrm{Tris} / \mathrm{HCl}, 0.1 \mathrm{M} \mathrm{NaCl}, 0.1 \mathrm{~mm}$ EDTA, pH 8.0, $25^{\circ} \mathrm{C}$. Values for porcine pancreatic A $\beta$-kallikrein B (pK1) were normalised to $230 \mathrm{BzArgOEt}^{-} \mathrm{U}_{253} / \mathrm{mg}$ protein (Fiedler et al., 1983) and for human urinary kallikrein (hK1) to 1100 AcP heArgOEt-U/mg protein (Geiger et al., 1980). Data for kinin release by hK1 were obtained with $3.2 \mu \mathrm{M}$ human L-kininogen in the experiment outlined in Fiedler and $\mathrm{Hinz}$ (1992) and those for $\mathrm{pK} 1$ were calculated from kinetic constants determined under somewhat different conditions (Fiedler and Hinz, 1992).

BKeq = brodykinin equivalents.

\section{Specific Activities and Substrate Specificities of the Guinea Pig TKs}

Specific activities of the three main TK preparations from the guinea pig, submandibular gpK1 and gpKla and coagulating gland/prostate complex (CPC) gpK2, were determined with the best $p$-nitroanilide substrate, i. e. D-ValLeuArg-pNA. Only in the case of gpK2, isolated from both submandibular glands and CPC, was an unusual increase in activity of about $10 \%$ observed during the first $10 \mathrm{~min}$ of the hydrolysis of this substrate; thereafter a constant rate (used for calculating the enzyme activity) was reached. This find ing provided further evidence of common enzyme activity in the two preparations. For the purposes of comparison, TKs from autolysed porcine pancreas ( $p K 1$ ) and from human urine (hK1) (Berg et al., 1992) are shown in Table 6. The data for pK 1 and hK 1 appear compatible with published results obtained under somewhat different conditions (Geiger et al., 1980; Fiedler et al., 1978; Olivera et al., 1987; Blaber et al., 1989). S pecific activities measured with D-ValLeuArg-pNA were remarkably similar for all TKs studied.

Rates of hydrolysis of a number of peptide p-nitroanilides by five different preparations of guinea pig TKs in comparison to $\mathrm{pK} 1, \mathrm{hK} 1$ and bovine trypsin are listed in Table 7, relative to a value of 100 given to the hydrolysis rate of D-ValLeuArg-pNA. The data for bovine trypsin compared favourably with published kinetic constants (Lottenberg et al., 1981), and thereby provided validation for the hydrolysis rates determined for the substrates with the TKs. The specificity patterns of the guinea pig TKs appear grossly similar to those of the other TKs (and totally different from that of trypsin). However, characteristic differences useful as identity criteria do exist. The pattern of substrate specificities obtained with pancreatic gpK1 was convincingly identical within experimental error with that for authentic gpK 1 from submandibular glands (Table 7). The same was true for submandibular gland gpK2 and for CPC gpK2 (Table 7). Only the SucPheLeuPhe-pNA activity of the submandibular enzyme preparation had a little higher value, a fact that could be easily explained by minor contamination with gpK 1 . The activity of hK 1, reported to have a high Phe activity (Chagas et al., 1995) with the latter substrate, was second only to that of gpK2. The guinea pig TKs as well as hK1 showed low activity on the partial kininogen sequence D-SerLeuMet-pNA (Friberger et al., 1982). In this respect they resembled porcine TK, where the efficiency of hydrolysis of the Met bond in kininogen could not be simulated by some low molecular mass model compounds (Fiedler and Hinz, 1992; Fiedler and Leysath, 1979; Fiedler et al., 1986).

\section{Kinin Release}

The type of kinin peptide released and the rates of kinin formation by the guinea pig TK preparations were determined at several reaction times with bovine L-kininogen as substrate (Table 6). With each enzyme a steady, gradually slowing down release occurred when kinin liberation was followed until at least $50 \%$ of the kinin content of the kininogen in the sample was hydrolysed. This observation indicated that kinins were not released preferentially from the one of the nicked forms present in the kininogen preparation (Fiedler and Hinz, 1992). Kallidin was always the main product formed. All of the enzyme preparations examined exhibited the characteristic property of a tissue kallikrein, namely the ability to cleave the Met bond of bovine kininogen. des-Arg-10-kallidin was released in parallel and in proportions corresponding to the content of $11 \%$ of releasable kinins present in form of des-Arg-370- 
Table 7 Rates of Hydrolysis of Peptide p-Nitroanilides Expressed Relative to that of D-ValLeuArg-pNA.

\begin{tabular}{|c|c|c|c|c|c|c|c|c|}
\hline p-Nitroanilide & $\begin{array}{l}\text { gpK1 } \\
\text { (pancreatic) }\end{array}$ & $\begin{array}{l}\text { gpK1 } \\
\text { (sub- } \\
\text { mandibular) }\end{array}$ & $\begin{array}{l}\text { gpKla } \\
\text { (sub- } \\
\text { mandibular) }\end{array}$ & $\begin{array}{l}\text { gpK2 } \\
\text { (sub- } \\
\text { mandibular) }\end{array}$ & $\begin{array}{l}\text { gpK2 } \\
\text { (CPC) }\end{array}$ & $\begin{array}{l}\text { pK1 } \\
\text { (autolysed } \\
\text { pancreas) }\end{array}$ & $\begin{array}{l}\text { hK1 } \\
\text { (urine) }\end{array}$ & $\begin{array}{l}\text { Trypsin } \\
\text { (bovine) }\end{array}$ \\
\hline D-ValLeuArg & 100 & 100 & 100 & 100 & 100 & 100 & 100 & 100 \\
\hline BzPheLeuArg & 8.4 & 7.0 & 6.3 & 15 & 17 & 6.8 & & 110 \\
\hline BzLeuLeuArg & 34 & 37 & 16 & 50 & 48 & 17 & & 160 \\
\hline D-ProPheArg & & 43 & 37 & & 84 & 67 & (10) & 110 \\
\hline BzProPheArg & 4.2 & 3.5 & 1.7 & 26 & 27 & 8.7 & & 40 \\
\hline ZPheArg & 3.8 & 3.7 & 1.8 & 8.8 & 9.1 & 4.2 & & 31 \\
\hline BzPheValArg & & 0.2 & 0.1 & & 1.5 & 1.1 & $(<1)$ & 140 \\
\hline ZGlyProArg & & 0.3 & 0.2 & & 0.2 & 1.3 & & 610 \\
\hline TosGlyProArg & & 0.35 & 0.2 & & 0.2 & 1.4 & (3.5) & 550 \\
\hline ZValGlyArg & 0.2 & 0.2 & 0.1 & 0.6 & 0.5 & 0.2 & & 310 \\
\hline ZLysArg & & $<0.1$ & $<0.1$ & & 0.1 & $<0.1$ & & 39 \\
\hline D-ValLeuLys & & 6.1 & 4.7 & & 4.3 & 6.6 & & 13 \\
\hline BzLeuLeuLys & 0.9 & 0.6 & 0.2 & 9.3 & 9.4 & 0.4 & & 37 \\
\hline SucPheLeuPhe & 13 & 14 & 2.4 & 0.3 & 0.01 & 0.4 & 4.6 & $<0.1$ \\
\hline SucPheProPhe & $<0.2$ & 0.1 & $<0.05$ & $<0.1$ & $<0.05$ & $<0.05$ & & \\
\hline SucAlaAlaProPhe & $<0.2$ & $<0.05$ & $<0.05$ & $<0.1$ & $<0.05$ & $<0.05$ & & \\
\hline SucGlyGlyPhe & & $<0.05$ & $<0.05$ & & $<0.05$ & $<0.05$ & & \\
\hline PyrPheLeu & & $<0.05$ & $<0.05$ & & 0.3 & $<0.05$ & & \\
\hline SucAlaAlaProLeu & & $<0.05$ & $<0.05$ & & $<0.05$ & $<0.05$ & & \\
\hline D-SerLeuMet & 1.6 & 1.8 & 0.6 & $<0.1$ & $<0.05$ & 0.2 & 0.5 & \\
\hline MeOSucAlaAlaP roMet & & $<0.05$ & $<0.05$ & & $<0.05$ & $<0.05$ & & \\
\hline
\end{tabular}

Conditions: $0.1 \mathrm{~mm}$ substrate, $0.1 \mathrm{M} \mathrm{Tris} / \mathrm{HCl}, 0.1 \mathrm{M} \mathrm{NaCl}, 0.1 \mathrm{~mm}$ EDTA, $\mathrm{pH} 8.0,25.0^{\circ} \mathrm{C}$. Data forhK 1 in parentheses were obtained at $37^{\circ} \mathrm{C}$ (Fiedler et al., 1978).

kininogen in the kininogen preparation used. Due to the presence of small amounts of Lys-361-nicked chains in the kininogen preparation (Fiedler and Hinz, 1992), a trace of bradykinin was found in the release experiments with gpK 1 and gpK 1 a. In contrast, both CPC and submandibular gpK 2 produced significant amounts of bradykinin which represented about $20 \%$ of total measurable kinin. As is evident from controls, this finding was not due to metabolism of kallidin to bradykinin. This result was regarded as an important common property of the gpK2 enzymes from the submandibular and coagulating/prostate organs. However, the additional formation of bradykinin by gpK 2 did not indicate a pronounced tendency of this enzyme to cleave the lysyl bond in kininogen. Bradykinin liberation by other TKs at a similar low rate would not be readily observed due to the large amounts of kallidin released.

The initial rate of kinin release from bovine L-kininogen by the most active guinea pig enzyme, gpK 1 (Table 6), appeared similar in value to the $462 \mu \mathrm{g}$ kallidin $\times \min ^{-1} \times$ $\mathrm{mg}^{-1}$ protein determined previously with the purified TK from submandibular glands under different experimental conditions (Fiedler etal., 1983). By comparison, the rate of kinin release by gpKla was about three-fold lower. The rate of kinin liberation from bovine L-kininogen determined for CPC gpK2 was similar to that obtained for submandibular gpK 2 (Table 6), amounting to as little as $3 \%$ of the specific activity of gpK 1 . Inspite of similar specific activities measured with D-ValLeuArg-pNA, the initial rate of kinin release from bovine L-kininogen by gpK 1 , the most active guinea pig enzyme, was 7 fold lower than the rate measured for pK1 (Fiedler and Hinz, 1992) and 13-fold lower than that obtained for hK1. The latter value was similar to published kinetic constants (Pierce and Guimaraes, 1976; Geiger et al., 1977; Maier et al., 1983).

When each TK was injected into the circulation of guinea pigs, the decrease in blood pressure considered to be due to kinin release from endogenous kininogen was greatest for submandibular gpK 1 , which had shown the fastest rate of kallid in release from bovine kininogen (Table 6). The present result for this enzyme is in reasonable agreement with the value of $300 \mu \mathrm{g}$ bradykinin equivalents/mg protein determined previously for guinea pig submandibular TK (Fiedler et al., 1983). Effects on the blood pressure diminished with decreasing kininogenase activity (Table 6). However, even gpK2 retained notable activity.

\section{Discussion}

The two guinea pig TKs, gpK1 (predominant in submandibular glands) and gpK2 (predominant in the CPC), are remarkably similar in their amino-terminal sequences: only 4 or 5 of the first 52 positions were found to differ. In this region, rapidly kinin-liberating 'true' TKs differ from TK-like enzymes from the male sexual tract in humans (as compiled in Schedlich et al., 1987) by as many as 17 or 20 , in the dog (Chapdelaine et al., 1991; Gauthier et al., 1994) by 
16, and in the rat (compilation in Wines et al., 1991) by 12 or 13 amino acid residues. The unusual sequence similarity cautioned against inferring the identity of a guinea pig TK preparation from results of amino-terminal sequencing alone.

The newly found third TK of the guinea-pig, termed gpK 1a, is indistinguishable from gpK 1 by amino-terminal sequencing. However, the nature of its enzymatic properties, as evidenced by the pattern of substrate specificities,

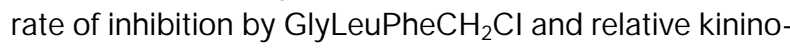
genase and blood pressure activities clearly indicate that gpK la is a distinct enzyme. Sequencing excluded intrachain splits as a cause of the differences. Whether gpKla is a product of post-translational modification, resulting from a loss of a C-terminal peptide or differences in amidation or glycosylation, or whether it is an allotypic variant or a product of a third TK gene may be clarified only by a complementary study of the TK gene locus of the guinea pig.

Identity of the whole protein part of gpK 2 detected in submandibularglands with authentic gpK 2 from CPC was supported, in addition to their similar elution pattern from benzamidine-Sepharose, by their similar specificity patterns, their unusual time-dependent substrate activation by D-ValLeuArg-pNA and their similar relative kininogenase activities, characterised by the release of significant amounts of bradykinin besides kallidin.

The very low content of TKs in guinea pig pancreas prevented complete purification and thorough characterisation of the two enzymes isolated from this source. The elution pattern from benzamidine-Sepharose, aminoterminal sequencing, patterns of substrate specificity and rates of inhibition by the $\mathrm{P}$ he chloromethyl ketone provided sufficient evidence that the two enzymes (Peaks $A$ and $B$ ) isolated from the pancreas are identical with gpK $1 a$ and gpK1, respectively.

Concerning the physiological roles of the three guinea pig TKs, gpK1 is the enzyme most efficiently releasing kallidin and lowering the blood pressure of the guinea pig. Therefore, this enzyme evidently is the 'true' TK in this animal. The occurrence of gpK 1 also in the pancreas is in accordance with this view. gpKla, which also occurs in the pancreas, had a similar efficiency in releasing kallidin, as well as lowering blood pressure. This enzyme may therefore well represent a variant of 'true' TK without an independent physiological role.

No otherTK-like enzyme besides gpK 2 was found in the $C P C$. This suggests that in CPC or in its secretions the biological functions of a TK-like enzyme would be mediated by gpK 2 alone. One possible function could be the release of kinin from kininogen. A 'true' TK able to release kallidin, and originating from the prostate, has been identified in human seminal plasma (Fink et al., 1985). Although the kallidin-releasing and guinea pig blood pressure regulating activities of gpK 2 were comparatively low, due to the large amounts of this enzyme occurring in these glands it could generate significant amounts of kinin and compensate for the absence of gpK1. Another TK-like enzyme in human semen is prostate-specific antigen (PSA; Christensson et al., 1990) which is unable to release kinin, but cleaves semenogelin at certain Tyr and Leu bonds. The predominant Arg, negligible $P$ he and low Leu specificities of gpK2 (Table 7) argue against a task analogous to PSA. The very low activities of all guinea pig TKs on ZLysArgpNA exclude these enzymes from the role of cleaving at pairs of basic amino acid residues.

Large TK multigene families have been identified only in the rat (Wines et al., 1991), mouse (Evans et al., 1987; Berg et al., 1992), and the African rat Mastomys (Bowcock et al., 1988), which are closely related species. Similarmultigene families comprising around 10 members have been reported for the trypsins of man (Emi et al., 1986), rat (Craik et al., 1984) and mouse (Stevenson et al., 1986). Evidently, the existence of such families of secretory serine proteinases does not necessarily imply that each of its members has a distinct or specific physiological function. The occurrence of not more than three and possibly even two products of independent TK genes in the guinea pig resembles the profile in man, where only three TKs are considered to exist (Baker and Shine, 1985; Schedlich et al., 1987; Riegman et al., 1992). Not more than 2 - 3 genes for such enzymes have also been reported in dog (Chapdelaine et al., 1991) and hamster (Howles et al., 1984). As pointed out also by Isackson and colleagues (Isackson et al., 1987), the existence in several species of only a few TKs does not support the suggestion that these enzymes convert many biologically important peptides into active compounds (Mason et al., 1983).

\section{Materials and Methods}

\section{Materials}

DEAE-Sephadex A-50, Sephadex G-100 and benzamidineSepharose were obtained from Pharmacia. Hydroxyapatite was Bio-Gel HTP from Bio-Rad. Diisopropyl fluorophosphate was obtained from Serva and $\mathrm{p}$-amidino-phenylmethanesulfonyl fluoride and D-P heP heArg $\mathrm{CH}_{2} \mathrm{Cl}$ from Calbiochem. 4-(2-Amino-ethyl)-benzenesulfonyl fluoride was a generous gift from Dr. J. Stürzebecher. D-ValLeuArg-pNA and D-ProPheArg-pNA were purchased from Kabi. D-ValLeuLys-pNA, D-SerLeuMet-pNA, BzLeuLeuArg-pNA and BzLeuLeuLys-pNA were provided by Kabi as generous gifts. BzPheLeuArg-pNA and ZValGlyArg-pNA were purchased from Medor, BzPheValArg-pNA from AB Bofors, TosGlyP roArg-pNA, NAD and yeast alcohol dehydrogenase from Boehringer Mannheim, SucAlaAlaProPhe-pNA from Novabiochem, and BzProPheArg-pNA, ZGlyProArg-pNA and bradykinin from Sigma. The otherp-nitroanilides and ACP heArgOEt $\cdot \mathrm{HCl}$ were obtained from Bachem. GlyLeuPheC $\mathrm{H}_{2} \mathrm{Cl} \cdot \mathrm{HBr}$ was prepared from ZGlyLeuPheC $\mathrm{H}_{2} \mathrm{Cl}$ (purchased from Paesel \& Lorei) analogous to the synthesis of $\mathrm{PheCH} \mathrm{H}_{2} \mathrm{Cl} \cdot \mathrm{HBr}$ (Segal et al., 1971).

Porcine pancreatic A $\beta$-kallikrein B (Fiedler et al., 1981; Kamada et al., 1990) treated with neuraminidase was obtained as generous gift from Bayer AG, Elberfeld. Human urinary kallikrein was kindly provided by Dr. R. Geiger (Geiger et al., 1980). Trypsin was bovine trypsin, TPCK-treated, from Merck. Isolation and properties of the bovine L-kininogen used are those outlined by Fiedler and Hinz (1992). 


\section{Determination of Enzyme Activity during Purification}

One unit $(U)$ of enzyme activity is defined as the amount hydrolysing $1 \mu \mathrm{mol}$ of substrate per min. Arg esterase activity was measured as previously described by Fiedler et al. (1978). The molar absorbance of NADH at $366 \mathrm{~nm}$ was taken from Ziegenhorn et al. (1976).

Arg amidase activity was assayed with $0.1 \mathrm{~mm}$ D-ValLeuArgpNA (Friberger et al., 1982) and Phe amidase activity with $0.1 \mathrm{~mm}$ SucPheLeuPhe-pNA at $25.0^{\circ} \mathrm{C}$ in $0.1 \mathrm{M} \mathrm{Tris} / \mathrm{HCl}, 0.1 \mathrm{~mm}$ EDTA buffer, $\mathrm{pH}$ 8.0. In the Phe amidase assay, the cuvette also contained $1 \%(\mathrm{v} / \mathrm{v})$ dimethyl sulfoxide in which the $10 \mathrm{~mm}$ stock solution of substrate had been prepared. $\mathrm{A}_{405 \mathrm{~nm}}$ was measured on a Kontron Uvikon 860 spectrophotometer. For the molar absorbance of $p$-nitroaniline a value of $9825 \mathrm{M}^{-1} \mathrm{~cm}^{-1}$ was used (Lottenberg and J ackson, 1983). Microtiter plate assays for screening of column eluates with one of these $p$-nitroanilide substrates (in a 5 -fold higher concentration) were run at room temperature in an analogous way. Each well contained a final volume of $200 \mu$ l, to which $1 \%$ of bovine serum albumin was added. Absorbance at $405 \mathrm{~nm}$ was read at intervals on a Dynatech MR 700 microplate reader.

To determine the protein concentration, $A_{280 n m}$ was measured. One $A_{280}$ unit was the amount of material showing an absorbance of 1 (at $1 \mathrm{~cm}$ light path) when contained in $1 \mathrm{ml}$ of solution. $A_{260}$ and $A_{320}$ were also measured as an indicator for the contribution of non-protein material to $A_{280}$ or a check for turbidity, respectively.

\section{Isolation of TKs from Submandibular Glands}

All operations were performed at $4-6^{\circ} \mathrm{C} .31 \mathrm{~g}$ of submandibular glands (which had been stored frozen) from male guinea pigs were homogenised in $100 \mathrm{ml}$ water in a Waring blendor and centrifuged. The supernatant was chromatographed on a $3.4 \times 22$ $\mathrm{cm}$ column of DEAE-Sephadex $\mathrm{A} 50$ with $8.0 \mathrm{I}$ of a linear gradient from 0 to $0.6 \mathrm{M} \mathrm{NaCl}$ in $50 \mathrm{~mm}$ Tris/ $/ \mathrm{HCl}, \mathrm{pH} 7.5$, at $75 \mathrm{ml} / \mathrm{h}$. Fractions with ACP heArgOEt esterase activity (beginning at $1.8 \mathrm{I}$ from the start) were pooled, dialysed and lyophilised. They were rechromatographed in the same way, except using a somewhat steeper gradient of only $5.0 \mathrm{l}$. As in the preceding step, care was taken to pool all detectable esterase activity (beginning after 1.6 I). After dialysing twice against two $10 \mathrm{I}$-changes of water and two $5 \mathrm{l}$-changes of $50 \mathrm{~mm}$ Tris/ $\mathrm{HCl}, \mathrm{pH} 7.5$, the material was applied at $20 \mathrm{ml} / \mathrm{h}$ to a $2.3 \times 10 \mathrm{~cm}$ column of benzamidinesepharose. After washing with $200 \mathrm{ml}$ of the dialysis buffer, elution was started with a linear gradient (1.1 I) of $0-0.6 \mathrm{M} \mathrm{NaCl}$ in $50 \mathrm{~mm}$ Tris/ $\mathrm{HCl}, \mathrm{pH} 7.5$, collecting $20 \mathrm{ml}$-fractions. These were assayed for AcPheArg-OEt-, D-ValLeuArg-pNA- and SucPheLeuPhe-pNAhydrolysing activities as described below. Fractions of the three activity peaks $A-C$ were pooled as indicated in Figure 1. Peak $A$ was rechromatographed on benzamidine-Sepharose as before.

Fractions $A, B$ and $C$ were separately chromatographed on hydroxyapatite and DEAE-Sephadex as exemplified here for peak $B$. The material was dialysed against 41 -changes of $1 \mathrm{~mm}$ potassium phosphate, $\mathrm{pH} 7.0$, and applied at $7 \mathrm{ml} / \mathrm{h}$ onto a $1.6 \times 12 \mathrm{~cm}$ column of Bio-Gel HTP. After washing with 1 column volume of the $1 \mathrm{~mm}$ buffer, elution was performed with $250 \mathrm{ml}$ of a linear gradient from 1 to $100 \mathrm{~mm}$ potassium phosphate, $\mathrm{pH}$ 7.0. The single peak of activity against the three substrates appearing after $60 \mathrm{ml}$ in the eluate was pooled and dialysed against two $250 \mathrm{ml}-$ changes of $50 \mathrm{~mm}$ Tris $/ \mathrm{HCl}, \mathrm{pH}$ 7.5. The final chromatography was performed at $2.5 \mathrm{ml} / \mathrm{h}$ on a $0.62 \times 10 \mathrm{~cm}$ column of DEAESephadex A-50 with $75 \mathrm{ml}$ of a linear gradient from 0 to $0.6 \mathrm{M} \mathrm{NaCl}$ in $50 \mathrm{~mm}$ Tris/ $/ \mathrm{HCl}, \mathrm{pH}$ 7.5. The single peak of activity appeared at about $30 \mathrm{ml}$. Fractions with the highest $A_{280} / A_{260}$ ratio and the highest specific activities were combined and stored at $-20^{\circ} \mathrm{C}$ in aliquots.

\section{Isolation of TK from Coagulating Gland/Prostate Complex}

$25 \mathrm{~g}$ of frozen CGC was homogenised with $125 \mathrm{ml}$ water, centrifuged and chromatographed on DEAE-Sephadex with 5.0 I of a linear gradient exactly as described for submandibular glands. Fractions with Arg esterase activity (beginning after 2.2 I) were pooled, dialysed against $40 \mathrm{I}$ water and lyophilised. The material was dissolved in $14 \mathrm{ml} 50 \mathrm{~mm}$ Tris/ $/ \mathrm{HCl}, \mathrm{pH} 7.5$, dialysed against 1.5 I of this buffer and applied to a $3.6 \times 140 \mathrm{~cm}$ column of Sephadex G-100 equilibrated with the same buffer containing $0.2 \mathrm{M} \mathrm{NaCl}$. Elution was performed at $30 \mathrm{ml} / \mathrm{h}$. The single peak of Arg esterase activity was dialysed against $4 \times 15$ I $1 \mathrm{~mm}$ potassium phosphate, $\mathrm{pH} 7.0$, and loaded onto a $5.4 \times 12 \mathrm{~cm} \mathrm{Bio-Gel}$ HTP column. The column was eluted at $90 \mathrm{ml} / \mathrm{h}$ with $2.7 \mathrm{I}$ of a linear gradient from 1 to $100 \mathrm{~mm}$ potassium phosphate, $\mathrm{pH} 7.0$. Again, the single Arg esterase activity peak beginning at 0.6 I was pooled.

An $8.0 \mathrm{ml}$ aliquot dialysed against the starting buffer was chromatographed on a $0.7 \times 3 \mathrm{~cm}$ column of benzamidine-Sepharose with $10 \mathrm{ml}$ of the starting buffer followed by $30 \mathrm{ml}$ of a linear gradient from 0 to $0.6 \mathrm{M} \mathrm{NaCl}$ in $50 \mathrm{~mm}$ Tris $/ \mathrm{HCl}, \mathrm{pH} 7.5$, at $1 \mathrm{ml} / \mathrm{h}$. The first artifact peak $A$ of Arg esterase was rechromatographed in the same way after regenerating the column with $15 \mathrm{ml}$ each of $0.5 \mathrm{M}$ $\mathrm{NaCl}$ in $0.1 \mathrm{M}$ Tris $/ \mathrm{HCl}, \mathrm{pH} 8.5$, and $0.5 \mathrm{M} \mathrm{NaCl}$ in $0.1 \mathrm{M} \mathrm{NaAc}, \mathrm{pH}$ 4.5, and equilibrating with $50 \mathrm{~mm}$ Tris/ $\mathrm{HCl}, \mathrm{pH}$ 7.5. The combined Arg esterase peaks $B$ and $B_{r}$ were finally chromatographed on a small column of DEAE-Sephadex as described for the submandibular enzyme.

\section{Isolation of TKs from Pancreas}

$50 \mathrm{~g}$ of frozen guinea pig pancreas was homogenised with $125 \mathrm{ml}$ water, centrifuged and chromatographed on DEAE-Sephadex as described. Fractions of the relatively broad peak of Arg esterase activity were pooled, dialysed against $40 \mathrm{I}$ water followed by 8 I of $50 \mathrm{~mm}$ Tris $/ \mathrm{HCl}, \mathrm{pH} 7.5$, and rechromatographed in the same way. After similar dialysis, the material from the only peak of Arg esterase was put onto a $1.3 \times 7.5 \mathrm{~cm}$ column of benzamidineSepharose, washed with $65 \mathrm{ml} 50 \mathrm{~mm}$ Tris $/ \mathrm{HCl}, \mathrm{pH} 7.5$, at $6.5 \mathrm{ml} / \mathrm{h}$ and eluted with $250 \mathrm{ml}$ of a linear gradient from $0-0.6 \mathrm{M} \mathrm{NaCl}$ in the same buffer. The main Arg esterase peak B was chromatographed on hydroxyapatite (scaled down by a factor of 5 ) and DEAE-Sephadex as described for submandibular TK peak B, while peak A was rechromatographed on DEAE-Sephadex only.

\section{Determination of Specific Activities and Substrate Specificities}

Submandibular gpK 1 and gpK1a and CPC gpK2 showed similar high $\mathrm{A}_{280} / \mathrm{A}_{260}$ ratios of 1.84 and 1.85 . Determination of protein concentrations from $A_{280}$ seemed therefore justified. Values for previously isolated TK from guinea pig submandibular glands $\left(\mathrm{A}_{280} / \mathrm{A}_{260}=1.85\right.$, a molar absorption coefficient $\epsilon_{280}$ of $35200 \mathrm{M}^{-1}$ $\mathrm{cm}^{-1}$ and $M_{r}=25900$ for the protein; Fiedler et al., 1983), were considered to apply to the present preparation of gpK 1 . Since gpK 1 a closely resembled gpK 1 , the same constants were used. The molar absorbance $\epsilon_{280}$ of CPC gpK 2 was calculated from 6 Tyr residues and 5 disulfides and assuming 5.5 Trp [as an average of 5 Trp of the Lys form and 6 Trp of the Trp form of the enzyme with a protein $M_{r}$ of 26300 (Dunbar and Bradshaw, 1987)] per molecule, as an average of $39800 \mathrm{~m}^{-1} \mathrm{~cm}^{-1}$ (individual values 39950 or 39580 ) by means of two sets of published absorbance increments (Edelhoch, 1967; Mach et al., 1992). This procedure was found to be valid in the case of TKs (Fiedler et al., 1983).

Activity measurements with $\mathrm{p}$-nitro-anilide substrates were conducted in $0.1 \mathrm{M} \mathrm{Tris} / \mathrm{HCl}, 0.1 \mathrm{M} \mathrm{NaCl}$ (to approximate physiological ionic strength), $0.1 \mathrm{~mm}$ EDTA (as precaution against inhibi- 
tion by contaminating heavy metal ions; Fiedler et al., 1978,1981), $\mathrm{pH} 8.0,25.0^{\circ} \mathrm{C}$, as standard conditions. The reactions in $1 \mathrm{ml} \mathrm{vol}$ ume were followed on a Kontron Uvikon 860 spectrophotometer at $405 \mathrm{~nm} . \epsilon_{405}=9935 \mathrm{M}^{-1} \mathrm{~cm}^{-1}$ (Lottenberg and J ackson, 1983) was used under these conditions. TK activities were assayed with $0.1 \mathrm{~mm}$ D-ValLeuArg-pNA from a $10 \mathrm{~mm}$ stock solution in water. Tests were usually run for 15 or $20 \mathrm{~min}$. When the necessary dilutions of the solutions of guinea pig TKs were made with Tris buffer or in polypropylene vessels, activity losses were observed. Therefore, enzyme solutions were diluted in Pyrex glass vessels with $1 \mathrm{~mm}$ potassium phosphate, $\mathrm{pH} 7.0$.

For the determination of substrate specificities, $1 \mathrm{~mm}$ stock solutions in water were prepared from the Lys- and Arg-p-nitroanilides, except BzPheLeu(and Val)Arg-pNA, BzLeuLeuArg(and Lys)-pNA and ZPheArg-pNA which were $0.5 \mathrm{~mm}$ and were warmed to $37^{\circ} \mathrm{C}$ prior to use to redissolve any crystallised material. $10 \mathrm{~mm}$ Phe-, Leu- and Met-p-nitroanilides were dissolved in dimethyl sulfoxide, and assays with these compounds contained $1 \%(\mathrm{v} / \mathrm{v})$ dimethyl sulfoxide. Substrate concentrations were checked by the absorbance at $405 \mathrm{~nm}$ after complete hydrolysis by bovine trypsin or chymotrypsin and adjusted to $0.1 \mathrm{~mm}$ in the assays. Water and buffer were filtered through $0.45 \mu \mathrm{m}$ cellulose nitrate membrane filters (Sartorius).

\section{Determination of N-Terminal Amino Acid Sequences}

Amino acid sequence analyses were performed on a 477A pulsed liquid phase sequencer equipped with an on-line 120A PTH analyser (both Applied Biosystems, Weiterstadt) according to the instructions of the manufacturer.

\section{Determination of Inhibition Constants}

Rates of inhibition of TK by active site-directed irreversible inhibitors were determined at $25.0^{\circ} \mathrm{C}$ in $0.05 \mathrm{M} \mathrm{Tris} / \mathrm{HCl}, 0.1 \mathrm{M} \mathrm{NaCl}$ $0.1 \mathrm{~mm}$ EDTA, $\mathrm{pH} 7.0$, under conditions [I] >>[E] . After starting the reaction by addition of inhibitor in the specified concentration, samples were withdrawn at intervals and assayed for residual enzyme activity with D-ValLeuArg-pNA and occasionally with SucPheLeuPhe-pNA. To increase the sensitivity of the latter assay, the Tris/ $\mathrm{NaCl}$ buffer $\mathrm{pH} 7.0$ just mentioned and $0.5 \mathrm{~mm}$ substrate [and consequently $5 \%(\mathrm{v} / \mathrm{v})$ dimethyl sulfoxide] were used. After graphical inspection of the data, inhibition constants $k_{i}^{\prime}$ were calculated according to the basic first order rate equation, $[E]=$ $\left[E_{0}\right] \cdot e^{-k^{\prime} \cdot t}$ or an appropriate expansion by nonlinear regression.

Rates of inhibition by $0.5 \mathrm{~mm}$ GlyLeuPheC $\mathrm{H}_{2} \mathrm{Cl}$ were also directly followed spectrophotometrically in $1 \mathrm{ml}$ cuvettes in the presence of $0.1 \mathrm{~mm} D$-ValLeuArg-pNA substrate under otherwise identical conditions for about 1.5 half lives, when less than $5 \%$ of the substrate was hydrolysed. Effective inhibition rate constants $\mathrm{k}^{\prime}$ were calculated for constant [S] and [I] by nonlinear regression according to $[\mathrm{P}]=[\mathrm{P}]_{0}+\mathrm{V}_{0}\left(1-\mathrm{e}^{-\mathrm{K}^{\prime} \cdot \mathrm{t}}\right) / \mathrm{k}^{\prime}$ (Gray and Duggleby, 1989).

\section{Determination of Kinin Release and Blood Pressure Decrease}

Kinin release from bovine L-kininogen $(4.5 \mu \mathrm{M})$ was followed at $25^{\circ} \mathrm{C}$ in $0.1 \mathrm{~m} \mathrm{Tris} / \mathrm{HCl}, 0.1 \mathrm{M} \mathrm{NaCl}, 0.1 \mathrm{~mm}$ EDTA, pH 8.0, in a volume of $0.44 \mathrm{ml}$. The reaction was started by the addition of enzyme (0.8 D-ValLeuArg-pNA-mU of gpK 1 or gpKla or $8 \mathrm{mU}$ of gpK2a). $100 \mu$ l samples were withdrawn at 5, 20, 60 and $200 \mathrm{~min}$, stopped with $20 \mu / 2 \mathrm{~N} \mathrm{HCl}$ and analysed for kinins in the isocratic pH 3 HPLC system (Fiedler and Geiger, 1988). Enzyme activity was determined in parallel with the assay with D-ValLeuArg-pNA in the presence of $0.1 \mathrm{~m} \mathrm{NaCl}$.
The hypotensive action of TKs was measured on adult (750 g) guinea pigs anaesthetised with intraperitoneal urethane. Carotid arterial blood pressure was recorded with a Statham pressure transducer linked to a Beckman R511A multichannel recorder. $100 \mu \mathrm{l}$-samples were injected in $10 \mathrm{~min}$-intervals through the cannulated external juglar vein and washed immediately into circulation with $200 \mu \mathrm{l} 0.9 \% \mathrm{NaCl}$ containing 3.5 units of heparin. Activities were match assayed against bradykinin standards.

\section{References}

Baker, A.R., and Shine, J . (1985). Human kidney kallikrein: CDNA cloning and sequence analysis. DNA 4, 445- 450.

Berg, T., Bradshaw, R.A., Carretero, O.A., Chao, J., Chao, L., Clements, J.A., Fahnestock, M., Fritz, H., Gauthier, F., MacDonald, R.J ., Margolius, H.S., Morris, B.J ., Richards, R.I., and Scicli, A.G. (1992). A common nomenclature for members of the tissue (glandular) kallikrein gene families. Agents Actions Suppl. 38, 19-25.

Bhoola, K.D., Figueroa, C.D., and Worthy, K. (1992). Bioregulation of kinins: kallikreins, kininogens, and kininases. Pharmacol. Rev. 44, 1-80.

Blaber, M., Isackson, P.J ., Marsters, J .C., J r., Burnier, J .P., and B radshaw, R.A. (1989). Substrate specificities of growth factor associated kallikreins of the mouse submandibular gland. Biochemistry 28, 7813- 7819.

Bothwell, M.A., Wilson, W.H., and Shooter, E.M. (1979). The relationship between glandular kallikrein and growth factor-processing proteases of mouse submaxillary gland. J . Biol. Chem. 254, $7287-7294$.

Bowcock, A.M., Fahnestock, M., Goslin, K., and Shooter, E.M. (1988). The NGF and kallikrein genes of mouse, the African rat Mastomys natalensis and man: their distribution and mode of expression in the salivary gland. Mol. Brain Res. 3, 165- 172.

Chagas, J .R., Portaro, F.C.V., Hirata, I.Y., Almeida, P.C., J uliano, M.A., J uliano, L., and Prado, E.S. (1995). Determinants of the unusual cleavage specificity of lysyl-bradykinin-releasing kallikreins. Biochem. J . 306, 63-69.

Chapdelaine, P., Gauthier, E., Ho-Kim, M.A., Bissonnette, L., Tremblay, R.R., and Dubé, J .Y. (1991). Characterisation and expression of the prostatic arginine esterase gene, a canine glandular kallikrein, DNA Cell Biol. 10, 49- 59.

Christensson, A., Laurell, C.B., and Lilja, H. (1990). Enzymatic activity of prostate-specific antigen and its reactions with extracellular serine proteinase inhibitors. Eur. J . Biochem. 194, $755-763$.

Craik, C.S., Choo, Q.-L., Swift, G.H., Quinto, C., MacDonald, R.J ., and Rutter, W.J . (1984). Structure of two related rat pancreatic trypsin genes. J . Biol. Chem. 259, 14255 - 14264.

Dunbar, J.C., and Bradshaw, R.A. (1985). Nerve growth factor biosynthesis: Isolation and characterisation of a guinea pig prostate kallikrein. J . Cell. Biochem. 29, 309-319.

Dunbar, J .C., and Bradshaw, R.A. (1987). Amino acid sequence of guinea pig prostate kallikrein. Biochemistry 26, $3471-3478$.

Edelhoch, H. (1967). Spectroscopic determination of tryptophan and tyrosine in proteins. Biochemistry 6, 1948- 1954.

Emi, M., Nakamura, Y., Ogawa, M., Yamamoto, T., Nishide, T., Mori, T., and Matsubara, K. (1986). Cloning, characterization and nucleotide sequences of two cDNAs encoding human pancreatic trypsinogens. Gene 41, $305-310$.

Erdös, E.G. (Ed.) (1979). Bradykinin, kallidin and kallikrein. Supplement, Handb. Exp. Pharm. 25 Suppl. (Berlin, Heidelberg, New York: Springer-Verlag). 
Evans, B.A., Drinkwater, C.C., and Richards, R.I. (1987). Mouse glandular kallikrein genes. Structure and partial sequence analysis of the kallikrein gene locus. J . Biol. Chem. 262, 8027 8034.

Fiedler, F., and Leysath, G. (1979). Substrate specificity of porcine pancreatic kallikrein. Adv. Exp. Med. Biol. 120, 261 - 271

Fiedler, F., and Geiger, R. (1988). Separation of kinins by highperformance liquid chromatography. Methods Enzymol. 163, $257-262$.

Fiedler, F., and Hinz, H. (1992). Kinetics of bond cleavages at kallidin release by tissue kallikrein: Cleavage of two peptide bonds in a single enzyme-substrate complex. Agent Action Suppl. 38, $82-88$.

Fiedler, F., Geiger, R., Hirschauer, C., and Leysath, G. (1978). Peptide esters and nitroanilides as substrates for the assay of human urinary kallikrein. Hoppe-Seyler's Z. Physiol. Chem. 359, 1667 - 1673.

Fiedler, F., Fink, E., Tschesche, H., and Fritz, H. (1981). Porcine glandular kallikreins. Methods Enzymol. 80, 493 - 532.

Fiedler, F., Lemon, M.J.C., Hirschauer, C., Leysath, G., Lottspeich, F., Henschen, A., Gau, W., and Bhoola, K.D. (1983). Purification and properties of guinea-pig submandibular-gland kallikrein. Biochem. J . 209, 125 - 134.

Fiedler, F., Hinz, H., and Lottspeich, F. (1986). Individual reaction steps in the release of kallidin from kininogen by tissue kallikrein. Adv. Exp. Med. Biol. 198, 283- 289.

Fink, E., Schill, W.-B., Fiedler, F., Krassnigg, F., Geiger, R., and Shimamoto, K. (1985). Tissue kallikrein of human seminal plasma is secreted by the prostate gland. Biol. Chem. HoppeSeyler 366, 917 - 924.

Frey, E.K., Kraut, H., and Werle, E. (1968). Das Kallikrein-KininSystem und seine Inhibitoren. (Stuttgart: Ferdinand Enke Verlag).

Friberger, P., Aurell, L., and Claeson, G. (1982). Chromogenic substrates for kallikreins and related enzymes. Agents Actions Suppl. 9, $83-90$

Gauthier, E.R., Dumas, C., Chapdelaine, P., Tremblay, R.R., and Dubé, J .Y. (1994). Characterisation of canine pancreas kallikrein cDNA. Biochim. Biophys. Acta 1218, 102 - 104.

Geiger, R., Mann, K., and Bettels, T. (1977). Isolation of human urinary kallikrein by affinity chromatography. J . Clin. Chem. Clin. Biochem. 15, 479-483.

Geiger, R., Stuckstedte, U., and Fritz, H. (1980). Isolation and characterisation of human urinary kallikrein. Hoppe-Seyler's $Z$. Physiol. Chem. 361, 1003- 1016.

Gray, P.J ., and Duggleby, R.G. (1989). Analysis of kinetic data for irreversible enzyme inhibition. Biochem. J . 257, 419 - 424.

Howles, P.N., Dickinson, D.P., DiC aprio, L.L., Woodworth-Gutai, M., and Gross, K.W. (1984). Use of a cDNA recombinant for the c-subunit of mouse nerve growth factor to localize members of this multigene family near the TAM-1 locus on chromosome 7 . Nucleic Acids Res. 12, 2791 - 2805.

Isackson, P.J ., Dunbar, J .C., and Bradshaw, R.A. (1987). Role of glandular kallikreins as growth factor processing enzymes: Structural and evolutionary considerations. J. Cell. Biochem. 33, $65-75$

Kamada, M., Ikekita, M., Kurahashi, T., Aoki, K., Kizuki, K., Moriya, H., Sweeley, C.C., Kamo, M., and Tsugita, A. (1990). Generation of a different type of $\beta$-kallikrein from porcine pancreatickallikrein by the action of chymotrypsin - observation of proteolytic processing occurring around "kallikrein autolysis loop" region. Chem. Pharm. Bull. 38, 1053 - 1057.
Kettner, C., Mirabelli, C., Pierce, J .V., and Shaw, E. (1980). Active site mapping of human and rat urinary kallikreins by peptidyl chloromethyl ketones. Arch. Biochem. Biophys. 202, 420-430.

Lottenberg, R., and J ackson, C.M. (1983). Solution composition dependent variation in extinction coefficients for $p$-nitroaniline. Biochim. Biophys. Acta 742, 558- 564.

Lottenberg, R., Christensen, U., J ackson, C.M., and Coleman, P.L. (1981). Assay of coagulating proteases using peptide chromogenic and fluorogenic substrates. Methods Enzymol. 80, $341-361$.

Mach, H., Middaugh, C.R., and Lewis, R.V. (1992). Statistical determination of the average values of the extinction coefficients of tryptophan and tyrosine in native proteins. Anal. Biochem. 200, $74-80$.

Maier, M., Austen, K.F., and Spragg, J . (1983). Kinetic analysis of the interaction of human tissue kallikrein with single-chain human high and low molecular weight kininogens. Proc. Natl. Acad. Sci. USA 80, 3928 - 3932.

Markwardt, F., Walsmann, P., Richter, M., Klöcking, H.-P., Drawert, J ., and Landmann, H. (1971). Amino-alkyl-benzol-sulfofluoride als Fermentinhibitoren. Pharmazie 26, 401 - 404.

Mason, A.J ., Evans, B.A., Cox, D.R., Shine, J ., and Richards, R.I (1983). Structure of mouse kallikrein gene family suggests a role in specific processing of biologically active peptides. Nature 303, 300 - 307.

Mayer, G., Bhoola, K.D., and Fiedler, F. (1989). Tissue kallikreins of the guinea-pig. Adv. Exp. Med. Biol. 247, $201-206$.

Moriwaki, C., Watanuki, N., Fujimoto, Y., and Moriya, H. (1974). Further purification and properties of kininogenase from the guinea pig's coagulating gland. Chem. Pharm. Bull. 22, 628633.

Oliveira, L., Araujo-Viel, M.S., J uliano, L., and Prado, E.S. (1987). Substrate activation of porcine pancreatic kallikrein by $\mathrm{N}$ derivatives of arginine 4-nitroanilides. Biochemistry 26, 5032 5035.

Pierce, J .V., and Guimaraes, J .A. (1976). In: Chemistry and Biology of the Kallikrein-Kinin System in Health and Disease, P isano, J .J . and Austen, K.F., eds. (USA: Government Printing Office), pp. $121-127$.

Riegman, P.H.J ., Vlietstra, R.J., Suurmeijer, L., Cleutjens, C.B.J.M., and Trapman, J. (1992). Characterisation of the human kallikrein locus. Genomics 14, 6-11.

Schedlich, L.J ., Bennetts, B.H., and Morris, B.J . (1987). Primary structure of a human glandular kallikrein gene. DNA 6, 429 437.

Segal, D.M., Powers, J.C., Cohen, G.H., Davies, D.R., and Wilcox, P.E. (1971). Substrate binding site in bovine chymotrypsin Agamma. A crystallographic study using peptide chloromethyl ketones as site-specific inhibitors. Biochemistry 10, 37283738.

Stevenson, B.J., Hagenbüchle, O., and Wellauer, P.K. (1986). Sequence organisation and transcriptional regulation of the mouse elastase II and trypsin genes. Nucleic Acids Res. 14 8307 - 8330

Wines, D.R., Brady, J .M., Southard, E.M., and MacDonald, R.J . (1991). Evolution of the rat kallikrein gene family: Gene conversion leads to functional diversity. J . Mol. Evol. 32, 476- 492.

Ziegenhorn, J ., Senn, M., and Bücher, T. (1976). Molar absorptivities of beta-NADH and beta-NADPH. Clin. Chem. 22, $151-$ 160. 